\title{
СИНДРОМ ВНУТРИЧЕРЕПНОЙ ГИПЕРТЕНЗИИ (ДИСТЕНЗИИ) У ДЕТЕЙ
}

\author{
*Рзаев Р.Н., Алиев 3.М.
}

Азербайджанский Медицинский Университет, кафедра неврологии и медицинской генетики, Баку

T ермин "внутричерепная гипертензия" в последнее время стал часто использоваться в повседневной практике неонатологов, педиатров и детских неврологов. Причем отмечается тенденция к тому, что, этот термин стал синонимом заболеваний нервной системы для родителей и трафаретом постановки стандартного диагноза для врачей, не умеющих или не желающих проводить тщательное обследование пациента. При этом постановка этого диагноза, нередко бездоказательно, служит обоснованием для последующего назначения медикаментозной терапии с использованием, в большинстве случаев, мочегонных препаратов. Это не только приводит к положительному результату, но и нередко способствует осложнениям (нарушение функции почек, иммунитета, электролитного баланса и др.).

Причиной синдрома "внутричерепной гипертензии" могут быть инфекционные заболевания ЦНС, последствия травмы головного мозга, новообразования и другие процессы, затрудняющие циркуляцию ликвора и венозный отток из полости черепа.

Патогенез внутричерепной гипертензии, слагается из ликворной гипертензии (вследствии гиперсекреции спинномозговой жидкости или механического сужения ликворных путей вследствии опухолей, спаечного процесса и т.д.) и нарущения венозного оттока из полости черепа (врожденные сосудистые аномалии, нарушение микроциркуляции, механическое сдавление вен и т.д.). Так как люмбальную пункцию с последующим измерением ликворного давления удается проводить не у всех детей, даже в стационаре, а исследование венозного оттока представляет определенные сложности, нами предложены более доступные критерии диагностики синдрома "внутричерепной гипертензии".

В клинике детской неврологии основными критериями для постановки диагноза "внутричерепная гипертензия" у детей грудного *e-mail: nailya43@rambler.ru возраста предложено считать: общее недомогание и громкий "мозговой" крик, быстрое нарастание размеров головки, сопровождающееся также напряжением большого родничка и расхождением швов черепа, частая рвота, не связанная с приемом пищи, ограничение движений глазного яблока вверх и в стороны, экзофтальм, сходящееся косоглазие, По мере прогрессирования процесса (вызванное повышением внутричерепного давления) наблюдается снижение зрения оканчивающееся атрофией диска зрительного нерва. Состояние ребенка резко ухудшается, появляется нарушение глотания, мышечный тонус повышается (особенно на нижних конечностях), развиваются судороги.

Но решающими критериями диагностики являются:

- исследования глазного дна (выявление отека и набухания соска зрительного нерва, расширение и извитость вен глазного дна, развитие вторичной атрофии зрительного нерва).

- данные сонографии (размер желудочков и субарахноидальных пространств с учетом динамических изменений при повторных исследованиях).

- данные КТ и МРТ (с целью выявления наличия отека мозга, особенностей конфигурации желудочков и ликворных пространств, выявление возможных причин окклюзии ликворных путей).

Что касается внутричерепной дистензии у детей. она может быть:

a) одним из механизмов не до конца контролируемого неврологом соматического заболевания;

б) относительно самостоятельного вялотекущего заболевания сосудов;

в) последствий некорректного длительного лечения внутричерепной гипертензии.

Симптоматика: общее недомогание, перепады эмоционального напряжения, медленно 
усиливающаяся тенденция к развитию астено-невротического синдрома.

Таким образом, применение вышеуказанных критериев уточнить наличие внутричерепной гипертензии или дистензии и позволяет ограничить неадекватный и небезразличный для здоровья детей, особенно раннего возраста, прием диуретиков и уменьшить количество нежелательных осложнений от их приема.
Лечение включает в себя прием диуретиков (в основном диакарба), венотонизируюших препаратов (анавенол, танакан), регуляции водно-электролитного баланса и других мероприятий. Лечение внутричерепной дистензии должно проводиться опытным клиницистом с учетом индивидуальной переносимости каждого назначаемого фармакологического препарата (субъективный "тест-контроль").

\title{
XÜLASO
}

\section{UŞAQLARDA KəLLӘDAXILI HİPERTNEZIYA (DISTTENZIYYA) SİNDROMU}

\author{
R.N.Rzayev, Z.M.Oliyev \\ Azərbaycan Tibb Universitetinin Nevrologiya vo tibbi genetika kafedrası, Bakı
}

Son zamanlar "kəllədaxili hipertenziya" sindromu pediatrların və uşaq nevroloqlarının gündəlik fəaliyyətində tez-tez istifadə olunur. Bu diaqnozun əsassız qoyulması sidikqovucu preparatların lazımsız təyin olunmasına gətirib çıxarır, bu da fəsadlara (böyrək fəaliyyətinin pozulması, elektrolit balansının dəyişməsi və s.) gətirib çıxarır.

Kəllədaxili hipertenziyanın və distenziyanın aşağıdakı diaqnostik meyarları təklif olunur:

- Kliniki simptomatika: başın ölçülərinin sürətli artması, həmçinin böyük əmgəyin gərginləşməsi və kəllə tikişlərinin aralanması, tez-tez yeməkdən ası1ı olmayan qusmanın olması, göz almasının yuxarı və yana hərəkətinin məhdudlaşması, ekzoftalm, daxili çəpgözlük. Bunlar mütləq əlavə meyarlarla təsdiq olunmalıdır.

- Göz dibinin müayinəsi: görmə siniri diskinin ödemləşməsi, şişməsi, venaların genişlənməsi və qıvrılması, görmə sinirinin ikincili atrofiyasının inkişafı.

- Sonoqrafiyanın naticələri.

- Baş beynin KT və MRT müayinələrinin nəticələri.

\section{SUMMARY}

\section{SYNDROME OF INTRACRANIAL HYPERTENSION (DISTENSION) IN CHILDREN}

\author{
R.N.Rzaiev, Z.M.Aliev \\ Azerbaijan Medical University, Chair of Neurology and medicine genetics, Baku
}

\begin{abstract}
The syndrome of "intracranial hypertension" is often used in the daily practice of pediatricians and child neurologists. Unjustified establishment of this diagnosis leads to unnecessary prescriptions of diuretics, and it leads to complications (infringement of action of the kidneys, changes in electrolyte balance, etc.).

The following diagnostic criteria of intracranial hypertension and distension are proposed:

- Clinical symptoms: rapid increase in the size of the head, including a tension of prefontanel, and extension of the cranial sutures, frequent vomiting which is not related to food, restriction of the movement of the eyeballs upward and to the side, exophthalmia, convergent strabismus. These features should be confirmed by additional criteria.

- Fundus examination: edema, swelling of the optic disc, expansion and tortuosity of the veins, the development of secondary atrophy of the optic nerve.

- The results of sonography.

- The results of CT- and MRI- examinations of the brain.
\end{abstract}

